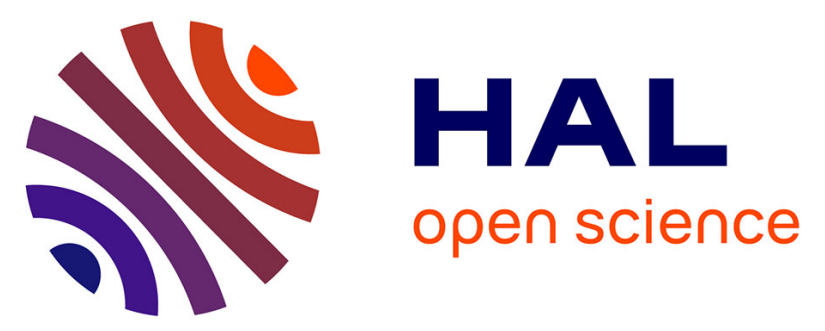

\title{
Design of Double Salient Interior Permanent Magnet Machine Based on Mutually Coupled Reluctance Machine for Increasing the Torque Density and Flux-Weakening Capability
}

Guangjin Li, Javier Ojeda, Emmanuel Hoang, Mohamed Gabsi, Cederic Balpe

\section{To cite this version:}

Guangjin Li, Javier Ojeda, Emmanuel Hoang, Mohamed Gabsi, Cederic Balpe. Design of Double Salient Interior Permanent Magnet Machine Based on Mutually Coupled Reluctance Machine for Increasing the Torque Density and Flux-Weakening Capability. IEEE ISIE 2010, Jul 2010, Bari, Italy. pp.1253 - 1258, 10.1109/ISIE.2010.5637001 . hal-00628831

\section{HAL Id: hal-00628831 \\ https://hal.science/hal-00628831}

Submitted on 4 Oct 2011

HAL is a multi-disciplinary open access archive for the deposit and dissemination of scientific research documents, whether they are published or not. The documents may come from teaching and research institutions in France or abroad, or from public or private research centers.
L'archive ouverte pluridisciplinaire $\mathbf{H A L}$, est destinée au dépôt et à la diffusion de documents scientifiques de niveau recherche, publiés ou non, émanant des établissements d'enseignement et de recherche français ou étrangers, des laboratoires publics ou privés. 


\title{
Design of Double Salient Interior Permanent Magnet Machine Based on Mutually Coupled Reluctance Machine for Increasing the Torque Density and Flux-Weakening Capability
}

\author{
G.J. LI ${ }^{1}$, Student Member, IEEE, X. OJEDA ${ }^{1}$, Student Member, IEEE, E. HOANG ${ }^{1}$, M. GABSI ${ }^{1}$, Member, IEEE, and C. \\ BALPE $^{2}$ \\ ${ }^{1}$ SATIE, ENS Cachan, CNRS, UniverSud, 61, av President Wilson, F-94230 Cachan, France \\ ${ }^{2}$ HISPANO-SUIZA, Division SAFRAN POWER, Rond-point Rene-Ravaud, BP42, 77551 Moissy-Cramayel, France \\ Guangjin.li@satie.ens-cachan.fr
}

\begin{abstract}
This paper presents a novel structure of double salient interior permanent magnet machine (DSIPM machine) based on mutually coupled switched reluctance machine (MCSRM). Due to its salient rotor structure, the DSIPM machine can have less magnetic and iron materials as well as higher dynamic response than conventional IPM machines. The comparison of electromagnetic performances in terms of self and mutual inductances, $\mathrm{d}$-axis and $\mathrm{q}$-axis inductances, cogging torque, reluctance torque, total torque, torque ripple coefficient and flux-weakening capability between the DSIPM machine 6/8 and the DSIPM machine $12 / 8$ has been realized. The numerical results based on Finite Element 2D shows that due to its much lower cogging torque and higher reluctance torque, the DSIPM machine 12/8 can produce higher total average torque than the DSIPM 6/8 at all phase current range. Furthermore, at low phase currents, the torque ripple of the DSIPM machine 12/8 is lower than that of the DSIPM machine $6 / 8$, while at high phase currents, the torque ripples of these two machines are similar. Comparing to MCSRM, the DSIPM machines can produce higher average torque with lower torque ripple. Moreover, due to their high d-axis inductances, the two DSIPM machines can have theoretically "infinite" flux-weakening capability with relatively lower short-circuit currents.
\end{abstract}

Keywords - double salient, $d$-axis and $q$-axis inductances, cogging torque, permanent magnets, flux-weakening capability.

\section{INTRODUCTION}

$\mathrm{C}$ OMPARING to surface-mounted permanent magnet machines, the interior permanent magnet machines (IPM machines) have higher torque density due to the saliency torque component and require lower magnetic and iron materials [1]. Furthermore, since the permanent magnets are inserted into the rotor, the permanent magnets have higher demagnetization withstand capability. Thus, this kind of machine is very appropriate for wide speed and constant power ranges operation in the flux-weakening mode. When to the mutually coupled switched reluctance machines (MCSRMs) (see the Fig. 1 (a)), the mutual inductances are employed to produce reluctance torque. Consequently, they have very high torque density. Moreover, in order to fully use the mutual inductances in torque production, we have to make sure that at least two phases are excited in the same time, and the signs of excited phase are opposite. Thus, the excitation mode should be bipolar, and the machine can be driven in BLAC mode. This kind of control leads to a simpler and cheaper inverter circuit than that of conventional SRM [2].

As known, the torque density can be significantly increased by increasing the number of rotor teeth in conventional SRM, and in this paper, the same study about the influence of increasing the rotor tooth number on the torque density for the MCSRM 6/4 has been realized. The cross-section of the MCSRM 6/8 is shown in the Fig. 1 (b). The two MCSRMs have the same stator as well as the same current distribution, which order is: $\mathrm{A}+\mathrm{A}-\_\mathrm{B}+\mathrm{B}-{ }_{-} \mathrm{C}+\mathrm{C}-{ }_{-} \mathrm{A}+\mathrm{A}-\mathrm{B}+\mathrm{B}-\mathrm{C}_{+} \mathrm{C}-$ (the direction is counter clockwise). As in the MCSRM 6/4, the mutual flux between phases exists, which can also be employed to produce torque. While according to the numerical results based on Finite Element Method (FEM 2D) shown in the Fig. 2, the increasing of rotor teeth cannot increase the average torque and decrease the torque ripple. On the contrary, the increasing of rotor teeth degrades considerably the electromagnetic characteristics of the MCSRMs.
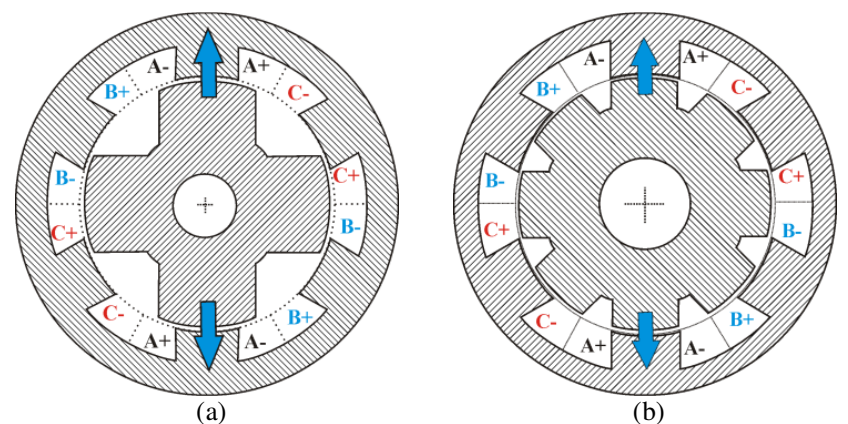

Fig. 1 The cross-sections of MCSRM 6/4 and MCSRM 6/8 and their flux directions with phase A excited in constant current 


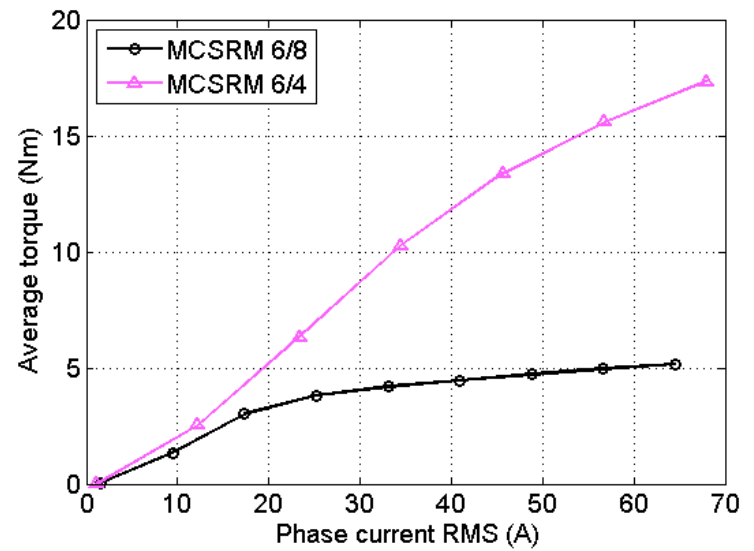

(a)

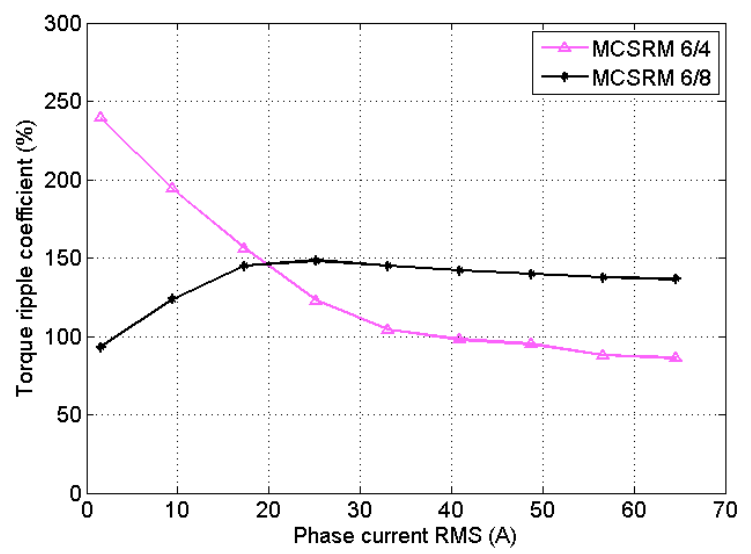

(b)

Fig. 2 Comparison of average torque and torque ripple coefficient between the MCSRM 6/4 and the MCSRM 6/8

In order to overcome this drawback and fully use the mentioned merits of the IPM machines and MCSRM, a kind of Double Salient Interior Permanent Magnet Machine is developed, which is shown in the Fig. 3. Due to its double salient structure, the reluctance torque as in the MCSRM can be employed, which makes that the DSIPM machines have high torque density and high flux-weakening capability with low torque ripple and low iron as well as magnetic materials. Other advantages of this kind of structure include a reduction of rotor inertia moment which makes the dynamic response quicker.

This paper presents two DSIPM machines, the crosssections of which are shown in the Fig. 3. These two machines have different stators while the rotors are the same. Moreover, in each rotor tooth, one magnet is inserted and all the magnets are radially magnetized. The first machine (Fig. 3 (a)) is a 6 slot, 8-pole DSIPM machine while the second one (Fig. 3 (b)) has 12 slots, 8 poles. Both the DSIPM 6/8 and DSIPM 12/8 machines have a short-pitched nonoverlapping winding configuration (i.e., each stator tooth is wound by one coil) and the current distributions in stator slots are periodic for these two machines $\left(\mathrm{A}+\mathrm{A}-{ }_{-} \mathrm{B}+\mathrm{B}-{ }_{-} \mathrm{C}+\mathrm{C}-\right.$ and repeat this distribution). Comparing to conventional DSIPM machines with full-pitched overlapping windings, this kind of winding configuration can have much shorter end-windings and low copper loss at the same phase currents. This is very suitable for embedded system applications, in which the additional end-winding due to full-pitched winding configuration is not acceptable [2].
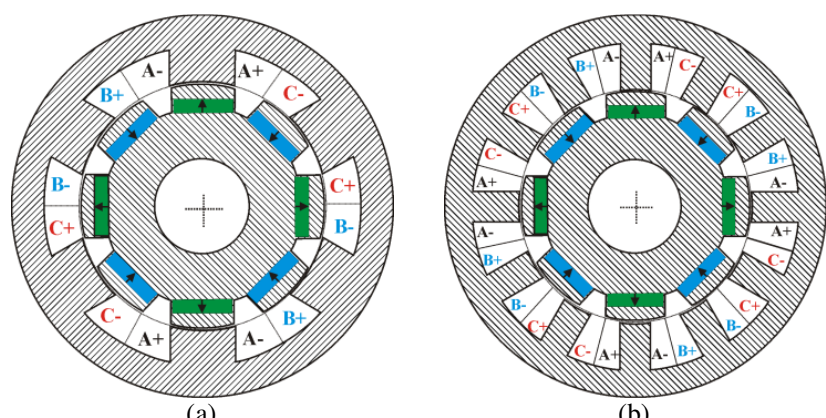

Fig. 3 The structures of double salient interior permanent magnet machines (DSIPM machines) 6/8 and 12/8

\section{FINITE ELMENT ANALYSIS}

\section{A. Self and mutual inductances}

In this paper, the Finite Element Method (FEM 2D) is employed in the study and for all the computations, the magnetic saturation can be taken into account. The open circuit magnetic field distributions for different rotor position of these two machines are shown in the Fig. 4.

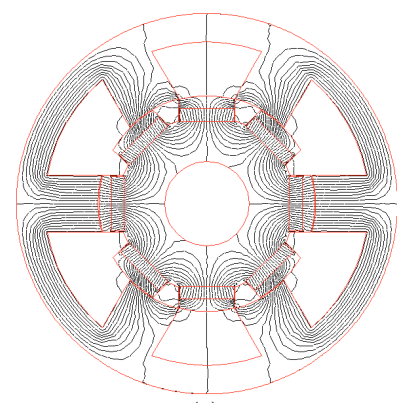

(a)

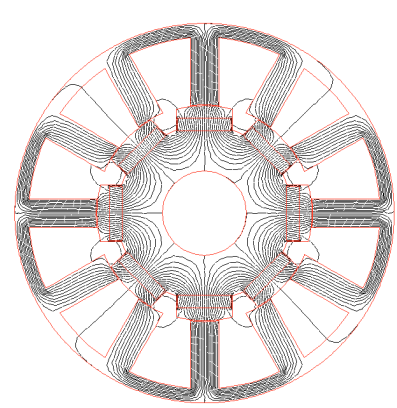

(a)

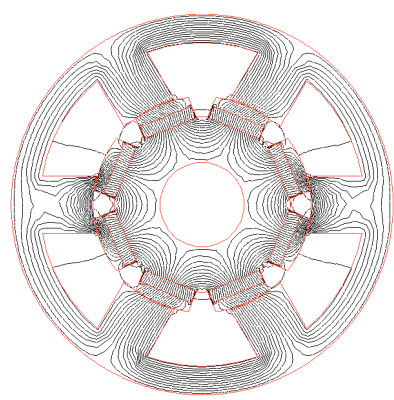

(b)

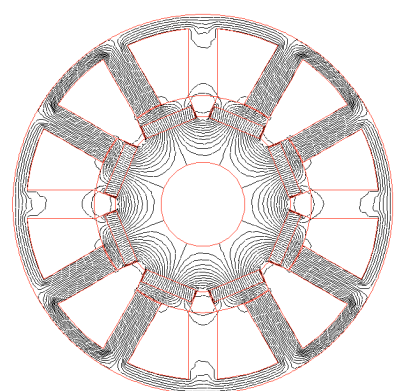

(b) (ii)

Fig. 4 Open-circuit flux distributions in DSIPM machine 6/8 and 12/8. (a) Angular position $\theta=0^{\circ}$, (b) Angular position $\theta=22.5^{\circ}$; (i) the DSIPM machine $6 / 8$ and (ii)the DSIPM machine 12/8

It is shown that, comparing to conventional IPM machines, the airspace between rotor teeth forms natural flux barriers which can reduce considerably the flux leakage and consequently increase the stator winding flux linkage as well as the torque density [3]. Furthermore, we can also insert circumferentially magnetized permanent magnets as interpole 
magnets in the airspace to decrease the flux leakage [4], while this method will certainly increase the cost of the machines and is not introduced in this paper.

With each phase excited independently in constant current and taking in to account the influence of magnets, the self and mutual inductances can be achieved such that [5]

$$
\begin{aligned}
L_{i} & =\frac{\psi_{i}-\psi_{m}}{I_{i}} \\
M_{i j} & =\frac{\psi_{i j}-\psi_{m}}{I_{j}} \\
i, j & =A, B, C \text { with } i \neq j
\end{aligned}
$$

$$
\begin{array}{ll}
\text { Where } & \\
L_{i} & \text { Phase self inductances of three phases } \\
M_{i j} & \text { Mutual inductances between phases } \\
I_{i} \text { and } I_{j} & \text { Current of three phases } \\
\psi_{m} & \text { Flux-linkage due to PM rotor } \\
\psi_{i} & \text { Flux-linkage of phase } i \text { with phase } i \text { excited } \\
\psi_{i j} & \text { Flux-linkage of phase } i \text { with phase } j \text { excited }
\end{array}
$$

In this paper, the phase $\mathrm{A}$ and phase $\mathrm{B}$ was taken as an example, and the finite element results of self and mutual inductances and their fundamental values versus rotor position of these two machines are shown as follows:

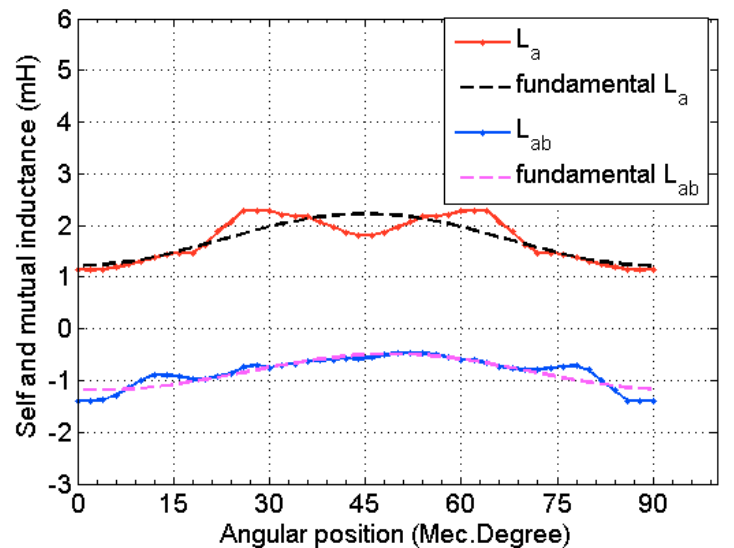

(a)

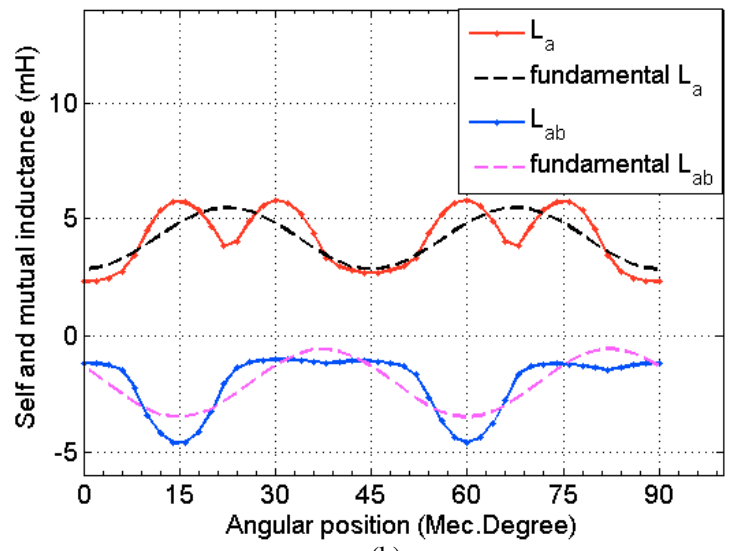

(b)

Fig. 5 The self and mutual inductances of DSIPM machine 6/8 and DSIPM machine $12 / 8$ (the current density $J=5 \mathrm{~A} / \mathrm{mm}^{2}$ )
According to the Fig. 5, it is shown that the average self and mutual inductances of DSIPM machine $6 / 8$ are respectively $1.7 \mathrm{mH}$ and $-0.85 \mathrm{mH}$, while the average self and mutual inductances of DSIPM machine 12/8 are respectively $4.2 \mathrm{mH}$ and $-2.05 \mathrm{mH}$. Furthermore, both the self and the mutual inductances (absolute value) of DSIPM machine 12/8 are respectively higher than those of DSIPM machine $6 / 8$, and the mutual inductances of both the DSIPM machine $6 / 8$ and the DSIPM machine 12/8 are approximately one half of their self inductances.

\section{B. The d-axis and q-axis inductances}

As has been shown in the Fig. 5, the waveforms of self and mutual inductances of these two DSIPM machines are not sinusoidal due to the harmonics, thus, in order to make sure that the d-q axis theory is available and can be employed for the computations in the following sections, only the fundamental value of flux and inductances are taken into account. In this paper, the three phases of machine are excited in sinusoidal current, thus, with the Park transformation and the previous hypothesis, the d-axis and q-axis current, $I_{d}$ and $I_{q}$ can be obtained. In order to obtain the $L_{d}$ and $L_{q}$, the rotor position is fixed at the $d$-axis and $q$-axis, and the machine is excited with $d$-axis and $q$-axis currents $I_{d}$ and $I_{q}$. The general expression of $L_{d}$ and $L_{q}$ can be obtained such that

$L_{d}=\frac{\psi_{d}\left(i_{d}, i_{q}, \theta\right)}{i_{d}}$ and $L_{q}=\frac{\psi_{q}\left(i_{d}, i_{q}, \theta\right)}{i_{q}}$

Due to the flux barriers between the permanent magnets, the $d$-axis and $q$-axis cross-coupling magnetic saturation between can be neglected [6], [7]. Thus, $L_{d}$ and $L_{q}$ can be simplified to $\psi_{d}=\psi_{d}\left(i_{d}, \theta\right)$ and $\psi_{q}=\psi_{q}\left(i_{q}, \theta\right)$. Consequently, the $L_{d}$ can be computed when the rotor is fixed at rotor position $0^{\circ}$ (daxis in this paper) and the machine excited with d-axis current $I_{d}\left(I_{a}=I, I_{b}=-I / 2\right.$ and $\left.I_{c}=-I / 2\right)$ while $L_{q}$ is calculated at rotor position $22.5^{\circ}$ and the machine excited with q-axis current $I_{q}\left(I_{a}=I, I_{b}=-I / 2\right.$ and $\left.I_{c}=-I / 2\right)$. After the numerical calculates based on Finite Element $2 \mathrm{D}$ (the magnetic saturation is taken into account), the d-axis and qaxis inductances versus current density for DSIPM 6/8 and DSIPM 12/8 are shown as follows:

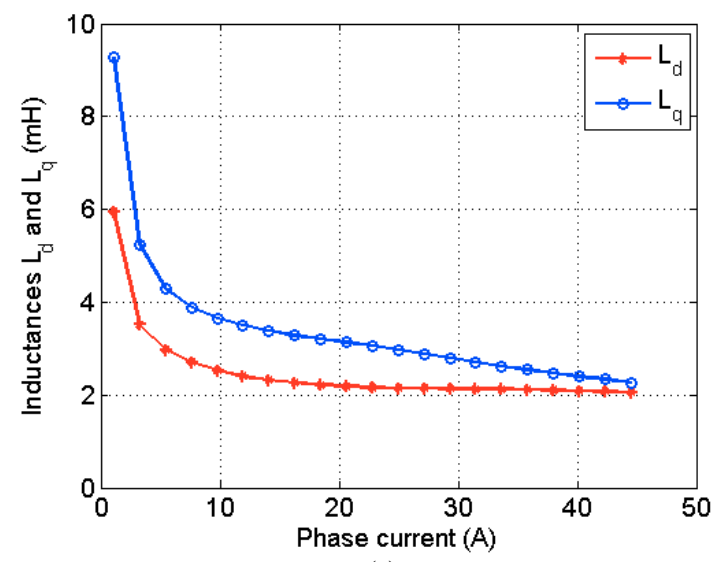

(a) 


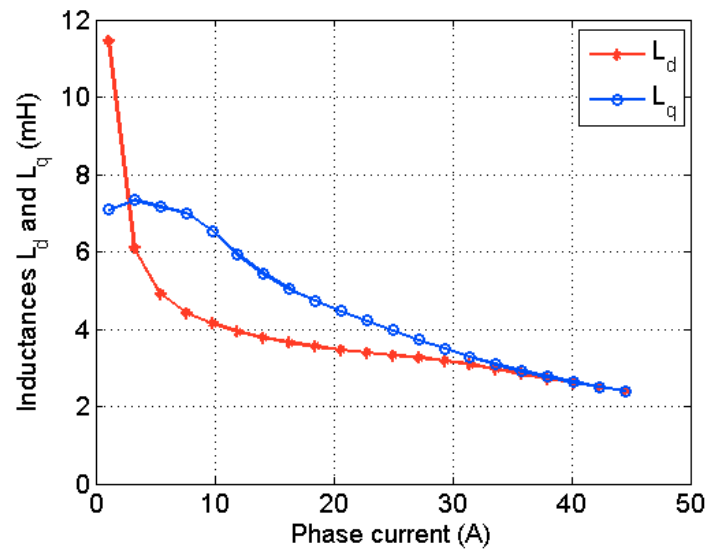

(b)

Fig. 6 The d-axis and q-axis inductances of DSIPM machine 6/8 and DSIPM machine 12/8. (a) DSIPM machine 6/8 and (b) DSIPM machine 12/8

According to the Fig. 6, it is shown that $d$-axis inductance $L_{d}$ of the DSIPM machine $6 / 8$ is always lower than $q$-axis inductance during all the current range. However, contrary to conventional IPM machines, the $d$-axis inductance $L_{d}$ of the DSIPM machine $12 / 8$ is much higher than the $q$-axis inductance $L_{q}$ at low phase currents. While at high phase currents, with the magnetic saturation of the machine, the $d$ axis inductance $L_{d}$ of the DSIPM machine 12/8 saturates quicker than the $q$-axis inductance $L_{q}$, consequently, $L_{d}$ becomes lower than $L_{q}$.

As known, the torque of the PM machines is derived from a general expression such that

$T=\frac{3}{2} p\left[\psi_{m} I_{q}+\left(L_{d}-L_{q}\right) I_{d} I_{q}\right]+\frac{1}{2} p \psi_{g}^{2} \frac{d R}{d \theta}$

Where $p$ is the number of pole-pairs, $R$ is the air-gap reluctance and $\psi_{g}$ is the magnet flux in air gap. In the equation (4), there are three terms which represent respectively three kinds of torque components, the first one is the excitation torque $3 / 2 p \psi_{m} I_{q}$ ), the second one is the reluctance torque ( $\left.3 / 2 p\left(L_{d}-L_{q}\right) I_{d} I_{q}\right)$ while the third one is the cogging torque $\left(1 / 2 p \psi_{g}^{2} d R / d \theta\right)$. Generally, the cogging torque will not contribute to the average torque because its average value is approximately zero, while the existence of cogging torque causes torque ripple in the instantaneous torque. Furthermore, theoretically, the higher the cogging torque, the higher the torque ripples.

It is well known that the flux weakening capability is determined by the ratio of $L_{d} I_{\max } / \psi_{m}$. Moreover, under the same inverter voltage and the same maximum inverter output current, the higher the ratio of $L_{d} I_{\max } / \psi_{m}$, the higher the flux-weakening capability [8]. Theoretically, when this ratio is equal to 1.0, an infinite flux-weakening capability is obtained. Thus, due to their relatively higher d-axis inductances, the DSIPM machines could have higher flux-weakening capability [9]-[11].

\section{Cogging torque and average torque}

The cogging torque is produced by the interaction between magnet flux-linkage and the air-gap reluctance of the PM machine. At low speed and low current density, it can cause very high torque ripple. To some degrees, this is an important source of the vibration and the acoustic noise of electric machines. There are numerous methods to reduce the cogging torque, such as skewing the stator slots and/or rotor magnets, shaping the magnets and optimizing the pole-arc, etc. While in this paper, the method of increasing the number of stator slots of a DSIPM machine 6/8 up to 12 has been chosen. After the numerical simulations (see Fig. 7), the cogging torque of the DSIPM machines is considerably reduced.

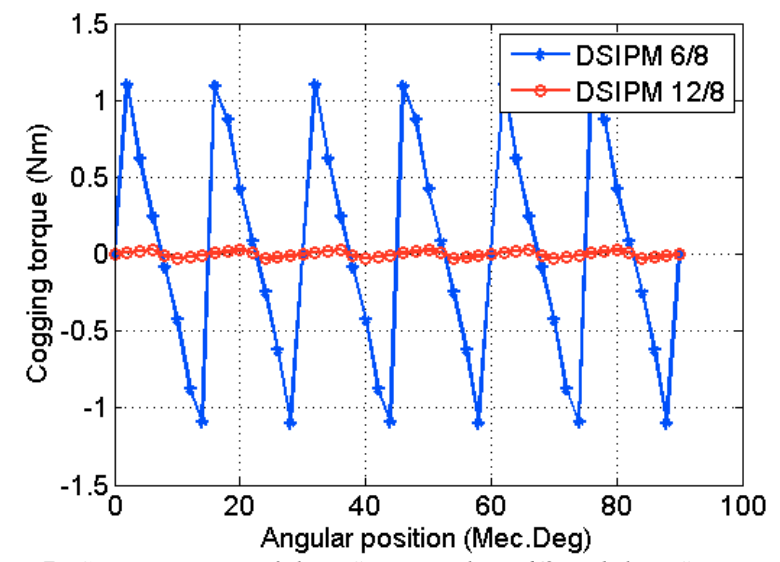

Fig. 7 Cogging torque of the DSIPM machine 6/8 and the DSIPM machine $12 / 8$

The reluctance torque is calculated at the condition that the magnet spaces are filled by air, thus the excitation torque and the cogging torque components can be neglected. The results of reluctance torque versus phase current RMS of the machines excited by sinusoidal currents is shown in the Fig. 8. It is shown that at high phase currents, the reluctance torque of DSIPM $12 / 8$ is lower than that of DSIPM 6/8. While due to the magnetic saturation, at high phase currents, the DSIPM $12 / 8$ saturates more quickly than the DSIPM 6/8. Consequently, the reluctance torque of DSIPM $12 / 8$ is lower than that of DSIPM 6/8.

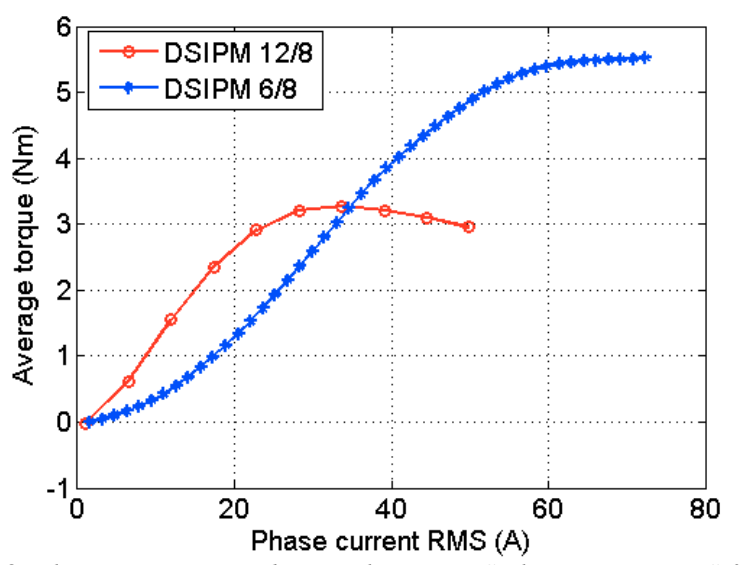

Fig. 8 The average torque due to reluctance VS phase current RMS for the DSIPM machine 6/8 and the DSIPM machine 12/8

The total average torque is obtained with the expression (4), and the results of total average torque versus phase current 
RMS is shown in the Fig. 9. It is shown that whatever the phase current, the DSIPM machine 12/8 can always produce the highest average torque among the three machines. However, the average torque of DSIPM machine $6 / 8$ is only slightly higher than that of MCSRM 6/4.

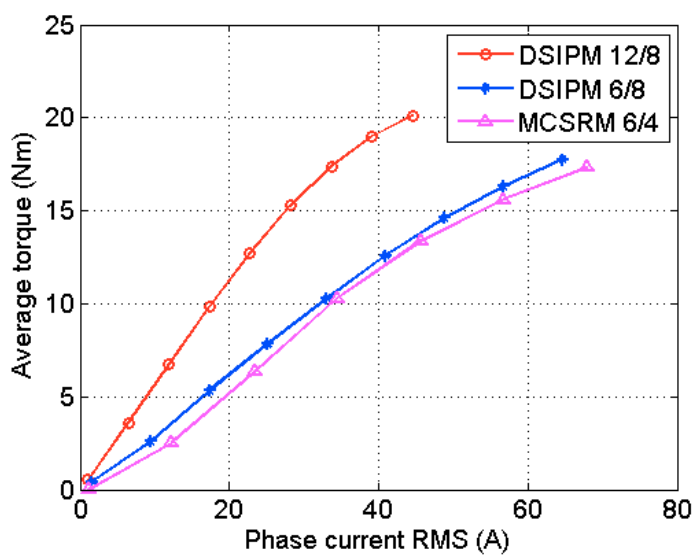

Fig. 9 The total average torque VS phase current RMS for the DSIPM machine 6/8 and DSIPM machine 12/8 as well as the MCSRM 6/4

In order to calculate the torque ripple coefficient, the expression (5) is employed.

$\Delta T=\left(T_{\max }-T_{\min }\right) / T_{a v}$

Where $\Delta T$ is the torque ripple coefficient, $T_{\max }, T_{\min }$ and $T_{a v}$ are respectively the maximum, the minimum and the average torque. The torque ripple coefficient versus phase current RMS of these two machines is shown in the Fig. 10.

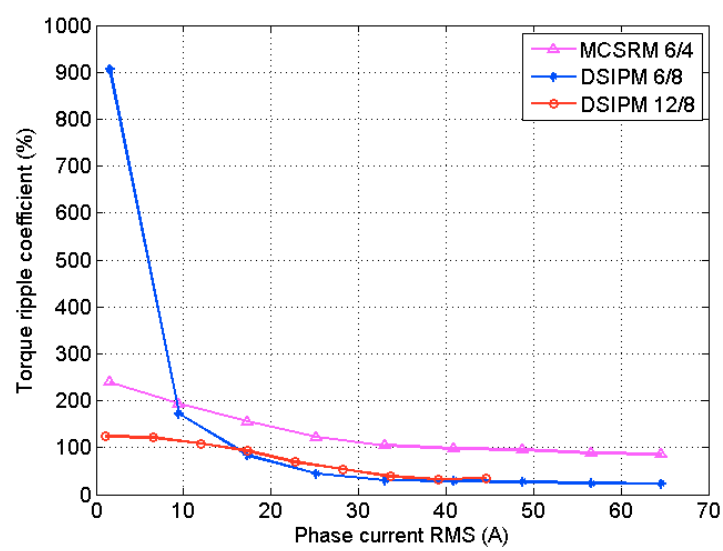

Fig. 10 The torque ripple coefficient VS phase current RMS for the DSIPM machine 6/8 and DSIPM machine 12/8 as well as the MCSRM 6/4

It is shown that except at very low phase currents, where the DSIPM machine $6 / 8$ have higher torque ripple than that of the MCSRM 6/4, the torque ripple of DSIPM machines are always lower than that of MCSRM 6/4. Between the two DSIPM machines, at low phase currents, the torque ripple of DSIPM machine 6/8 is much higher than that of DSIPM 12/8. This is because that at low phase currents, both the excitation torque and the reluctance torque of these two machines are low, while the cogging torque of the DSIPM machine $6 / 8$ is much higher than that of DSIPM machine 12/8. Thus, the total torque of the DSIPM machine $6 / 8$ has higher ripple than that of DSIPM machine 12/8. While with the increase of phase currents, the torque ripples of these two machines decrease, and the torque ripple of DSIPM machine 6/8 decreases more quickly than that of DSIPM machine 12/8. Consequently, these two machines have similar torque ripples at high phase currents.

\section{Flux-weakening capability}

As mentioned in previous sections, these machines are excited with sinusoidal currents and controlled by PWM. The peak value of fundamental phase voltage is

$U_{\max }=1 / 2 U_{D C}$

And the rated mechanical angular speed as well as the maximum speed is calculated such that:

$\Omega_{b}=\frac{U_{\max }}{p \sqrt{\left(L_{q} I_{\max }\right)^{2}+\left(\psi_{m}\right)^{2}}}$ with $I_{q}=I_{\max }$
$\Omega_{\max 1}=\frac{U_{\max }}{p \psi_{m}}$
$\Omega_{\max 2}=\frac{U_{\max }}{p \psi_{m}(1-r)}$ with $r<1$

Where $\Omega_{b}, \Omega_{\max 1}$ and $\Omega_{\max 2}$ are respectively the rated mechanical angular speed, the maximum mechanical angular speeds without and with flux-weakening operation; $r$ is the ratio of $L_{d} I_{\max } / \psi_{m}, I_{\max }$ is the phase current for obtaining the maximum torque. After the numerical calculates (FEM 2D), the results are shown in the Table 1.

Table 1

Comparison of the flux-weakening capability of the two DSIPM machines

\begin{tabular}{lll}
\hline \hline & DSIPM 6/8 & DSIPM 12/8 \\
\hline Short-circuit current $I_{s c}(\mathrm{~A})$ & 30 & 25 \\
Maximum current $I_{\max }(\mathrm{A})$ & 27 & 18.6 \\
Maximum couple $T_{\max }(\mathrm{Nm})$ & 8.7 & 9.6 \\
Winding turns per coil $(\mathrm{N})$ & 40 & 40 \\
Inductance $L_{d}(\mathrm{mH})$ & 1.6 & 3.3 \\
Inductance $L_{q}(\mathrm{mH})$ & 2.4 & 4.3 \\
$r=L_{d} I_{\max } / \psi_{m}$ & 1.09 & 0.92 \\
$\psi_{m}(\mathrm{mWb})$ & 40.25 & 69.23 \\
dc-link voltage $\mathrm{U}_{\mathrm{DC}}(\mathrm{V})$ & 270 & 270 \\
Rated mechanical angular speed $\left(\Omega_{b}\right)$ & & \\
$(\mathrm{rpm})$ & 4178 & 3003 \\
Maximum mechanical angular speed & & \\
without flux-weakening $\left(\Omega_{\max }\right)(\mathrm{rpm})$ & 8007 & 4655 \\
\hline \hline
\end{tabular}

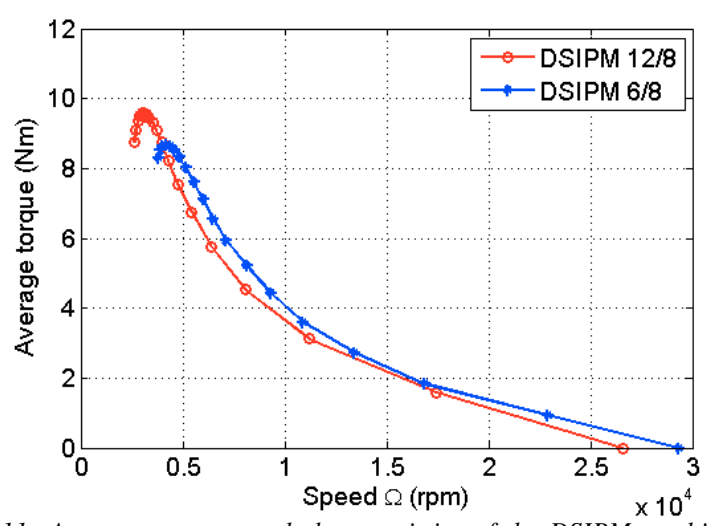

Fig. 11 Average torque-speed characteristics of the DSIPM machines (6/8 and 12/8) 
It was shown that these two DSIPM machines have high ratio of $L_{d} I_{\max } / \psi_{m}$. Thus, they can have considerably wide operating speed range. Furthermore, the ratio of $L_{d} I_{\max } / \psi_{m}$ of DSIPM machine 6/8 is greater than 1.0, thus, theoretically, the flux-weakening capability of which can be "infinite". However, it should be noted that due to the magnetic saturation of the machine and the influence of cross-coupling magnetic saturation, the maximum speed of the DSIPM machines with flux-weakening operation cannot be infinite, and which is finally shown in the Fig. 11.

At high phase currents, the $d$-axis inductances of the two DSIPM machines can be considered as constant (see the Fig. 6), this makes that the prediction of mechanical angular speed of these DSIPM machines in flux-weakening operation mode is possible. Since for all the PM machines, the short-circuit current $I_{s c}$ can be calculated such that

$I_{s c}=\frac{\psi_{m}}{L_{d}}$

A relationship between the phase current and the mechanical angular speed can consequently be achieved as

$I=I_{s c}\left(1-\frac{\Omega_{\max 1}}{\Omega}\right)$ with $\Omega \geq \Omega_{\max 1}$

With the equation (10), the short-circuit current $I_{S c}$ is obtained as shown as in the Fig. 11 (when the $d$-axis flux linkage $\psi_{d}$ is zero, the $d$-axis current $I_{d}$ is equal to the short-circuit current $\left.I_{s c}\right)$. Furthermore, with the equation (11), if any three variables are determined, the fourth one can be calculated.

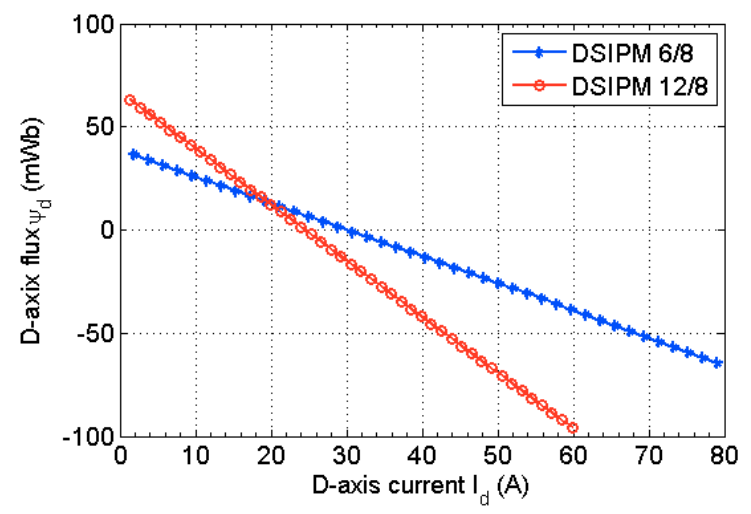

Fig. 12 d-axis flux-linkage $\psi_{d}$ VS d-axis current $I_{d}$ for these two DSIPM machines (6/8 and 12/8)

\section{CONCLUSION}

A novel structure of double salient interior permanent magnet machine (DSIPM machine) based on mutually coupled switched reluctance machine (MCSRM) is developed, the comparison of electromagnetic performances between the DSIPM machine 6/8 and the DSIPM machine 12/8 was realized, which is in terms of self and mutual inductances, daxis and q-axis inductances, cogging torque, reluctance torque, total torque, torque ripple coefficient and flux-weakening capability.
The numerical results based on Finite Element 2D has shown that due to their double salient structure, the reluctance torque is employed, and the DSIPM machines (6/8 and 12/8) can produce higher average torque with lower torque ripple coefficient than that of MCSRM 6/4. Between the two DSIPM machines, at whatever the phase current, the total average torque of DSIPM machine $12 / 8$ is always higher than that of DSIPM machine 6/8. Moreover, due to its much lower cogging torque, the DSIPM machine $12 / 8$ can produce much lower torque ripple than the DSIPM machine $6 / 8$ at low phase current, while at high phase currents, the torque ripples of these two machines are similar.

Due to their high $d$-axis inductances of these two DSIPM machines, theoretically, the infinite flux-weakening capability can be achieved.

\section{Acknowledgement}

The authors acknowledge the contributions of the colleagues of the SATIE laboratory, ENS-Cachan, Paris, France, and also the support of industrial organizations, especially the national scientific research centre of France (CNRS), and the SAFRAN POWER Division of HISPANOSUIZA Company.

\section{References}

[1] Z. Q. Zhu, S. Ruangsinchaiwanich, N. Schofield and D. Howe, "Reduction of Cogging Torque in Interior-Magnet Brushless Machines', IEEE Trans. On Magnetics, vol. 39, no. 5, Sep. 2003, pp. 3238-3240.

[2] G. J. Li, X. Ojeda, S. Hlioui, E. Hoang, M. Gabsi and C. Balpe, "Comparative Study of Switched Reluctance Motors Performances for Two Current Distributions and Excitation Modes', IEEE IECON 2009, Porto, Portugal, Nov. 2009.

[3] L. Xu, L. Ye, L. Zhen and A. El-Antably, "A New Design Concept of Permanent Magnet Machine for Flux Weakening Operation", IEEE Transactions on Industry Applications, Vol.31, No.2, March/April 1995, pp.373-378.

[4] Z. Q. Zhu and D. Howe, "Electrical Machines and Drives for Electric, Hybrid, and Fuel Cell Vehicles,', Proc. IEEE, vol. 95, no. 4, pp. 746765, Apr. 2007.

[5] Z. Q. Zhu, Y. Pang, D. Howe, S. Iwasaki, R. Deodhar and A. Pride, "Analysis of Electromagnetic Performance of Flux-Switching Permanent-Magnet Machines by Nonlinear Adaptive Lumped Parameter Magnetic Circuit Model', IEEE Trans. On Magnetics, vol. 41 , no. 11 , Sep. 2005 , pp. 4277-4287.

[6] E. C. Lovelace, T. M. Jahns and J. H. Lang, "A Saturating LumpedParameter Model for an Interior PM Synchronous Machine" IEEE Trans. Ind. Applicat., vol. 38, pp. 645-650, no.3, May./Jun. 2002.

[7] Y. S. Chen, Z. Q. Zhu and D. Howe, "Calculation of d- and q-Axis Inductances of PM Brushless ac Machines Accounting for Skewing," IEEE Trans. On Magnetics, vol. 41, no. 10, Oct. 2005, pp. 3940-3942.

[8] T. J. E. Miller, M. Popescu, C. Cossar and M. McGilp, "Performance Estimation of Interior Permanent-Magnet Brushless Motors Using the Voltage-Driven Flux-MMF Diagram', IEEE Trans. On Magnetics, vol. 42, no. 7, Jul. 2006, pp. 1867-1872.

[9] W. L. Soong and N. Ertugrul, "Field-Weakening Performance of Interior Permanent-Magnet Motors,' IEEE Trans. Ind. Appl., vol. 38 , no. 5, pp. 1251-1258, Sep./Oct. 2002.

[10] T. M. Jahns, "Torque Production in Permanent Magnet Synchronous Motor Drives with Rectangular Current Excitation,"' IEEE Trans. Ind. Appl., vol. IA-20, no. 4, pp. 803-813, 1984.

[11] T. M. Jahns, "Flux-Weakening Regime Operation of an Interior Permanent-Magnet Synchronous Motor Drive," IEEE Trans. Ind. Appl., vol. 23, no. 4, pp. 681-689, 1987. 